\title{
日本で使用されているジオグリッドの材料特性と引き抜き特性
}

\author{
東京工業大学工学部 桑野二郎・高橋章浩・木村博憲
}

具在ジオグリッドには種々の製品があり広く使用されている。個々のジオグリッドに関しては材料特性 や引き抜き特性などが調心゙られているが、それらの全く異なる材料特性が引き抜き特性にどのように影 響するか、相互比較は必ずしもなされていない。そこで、日本で使用されている主なジオグリッド11種 類の材料特性と引き抜き特性の関係を調べてみた。これらのジオグリッドは土木研究センターの審査証 明を取得しており、その報告書として公表されているデータについて、形状・破断強度・伸び特性など の材料特性と引き抜き強度・引き抜け量などの引き抜き特性の関係を整理してみた。 キーワード：ジオグリッド、材料特性、引き抜き特性

\section{Material properties and pullout characteristics of geogrids used in Japan}

J. Kuwano, A. Takahashi and H. Kimura: Department of Civil Engineering, Tokyo Institute of Technnology

Various geogrids are widely utilized now. Material properties as well as pullout resistances of respective geogrids are investigated. However the properties of those geogrids are rarely compared each other. In this report, the material properties and the pullout resistances of eleven major geogrids used in Japan are summarized and discussed based on the data presented in the reports published by Public Works Research Center. Pullout resistances and strains at pullout failure are correlated with the properties of geogrids, tensile strength and tensile stiffness for example.

Keywords: Geogrid, Properties of geogrid, Pullout characteristics 


\title{
日本で使用されているジオグリッドの材料特性と引き抜き特性
}

\author{
東京工業大学工学部 桑野二郎・高橋章浩・木村博憲
}

\section{1.はじめに}

ジオグリッドによる地盤補強工法は広く用いられており、盛土構造物などの安定性向上に大きく寄与 している。日本でも現在多くの種類のジオグリッドが使用され、実績を上げている。財団法人土木研究 センターでは建設大臣の認定を受け、「土木系材料・技術審査証明事業」を実施している。各社で開発 されたジオグリッドは、引張強度、交点強度、クリープ特性、土との摩擦特性、耐衝撃性、耐候性、耐 薬品性などに関するほぼ共通した仕様で実施された試験結果に基づき審査され、その品質や性能に関し て証明が与えられている。また、その内容に関しては報告書が作成され公表されている。

ところで、製品開発において各社は、それぞれの得意とする素材と技術を用いて行われていると思わ れる。その品質や性能は上記のような審査を経ているが、それぞれの特性の相互比較というものは特に は行われていない。Akagi ${ }^{1)}$ はほぼ同一の製品基準強度を有する5種類のジオグリッドについて、引張 特性、クリープ特性、引き抜き特性を取りまとめ、破断時の伸びが大きく異なること、設計長期強度は 製品基準強度の 60 〜 65\%に低減させる必要があるが破断ひずみは短期強度とほぼ同じであること、など を述べている。本報告では、1991年から1997年にかけて土木研究センターから公表された11冊の報告書 から、主に力学特性に関係すると思われるデータを抽出して取りまとめるとともに、各ジオグリッドの 特性が引き抜き特性とどのような関係を示すか検討したものである。

\section{2. データ概要}

先に述ベたように、土木技術センターから「民間開発建設技術の技術審査・証明事業認定規定に基づ く土木系材料技術・技術審查証明報告書」として公表された一連の報告畵から、以下の11種類について データを取りまとめた。公表順に（括弧内は年.月）、アデム(1991.8)、テンサー(1992.2)、パワーグ リッド(1992. 10)、フォートラック (1993.2)、ネステム(1993.6)、コスモグリッド(1995.3)、セルフォ ース(1995. 3)、アデムGタイプ／Fタイプ(1997.2)、トレグリッド(1997.2)、テンサー(1997.5)、セル フォースFタイプ(1997.12)である。これらを上記順番とは全く関係なく製品名 $\mathrm{A} \sim \mathrm{K}$ し、表 $1 \sim 6$ に力学特性に関係すると思われるものを取り出してまとめてある。なお各製品はそれぞれ引張強度など の異なる複数の品番を含んでいるため、それらはA1〜Anなどとして区別した。取りまとめたのは表にも 見られるように、素材構成、目合い、引張試験・交点強度試験・クリープ試験というジオグリッド自体 の力学特性に関するもの、さらには土中での挙動に関係する耐衝撃試験・土中引き抜き試験及び試料土 のせん断試験結果である。なおスペース節約のため、以上の大項目の表記は表 2 以降では省略してある。

さて、まず素材構成であるが、芯材としては合成化合物のものが大部分であるが、ガラス繊維を使用 しているものもある。また多くが芯材を被覆材で覆う形式を取っているが、被覆材を使用していないも のもある。また目合いは $6 \mathrm{~mm}$ から $100 \mathrm{~mm}$ ののと様々であるが、大体20～30 mm程度のものが多いようであ る。また縦と横の目合いもどちらが大きいかは製品により異なる。 
引張試験結果を見ると、引張強度は約 $13 \mathrm{kN} / \mathrm{m} か ら 260 \mathrm{kN} / \mathrm{m}$ と大変幅広いが、印象としては $70 \mathrm{kN} / \mathrm{m}$ 前後 のものが多いように思われる。また破断時引張ひずみについても、約 $2 \%$ 小さいものからから20\%を超 すものまで、芯材によって大きく異なっている。引張剛性に関しては数值での報告がなされていないた め、引張試験で得られた応力〜ひずみ関係から、ほぼ直線的な関係を示すと見なせる原点とピーク強度 050\%の点を結んだ直線の傾きを求め、データとして用いた。製品によって、ほぼ直線的な関係を亦し て突然破断するものや、やや緩やかなカーブを描くものなど色々であるが、概ね破断時引張ひずみが大 きいものでは引張剛性は低い。值としては約 $180 \mathrm{kN} / \mathrm{m}$ から約 $11950 \mathrm{kN} / \mathrm{m}$ と60倍以上もの違いがある。

交点強度に関しては、これも約70Nから約2950Nと約40倍もの開きがあった。また、引張強度の高さと 交点強度の高さは必ずしも対応しておらず、両者が必ずしもバランスしていないようである。

$10^{6}$ 時間（約100年）後にも破断に対して十分に安全であると推定されるクリープ限界強度は、それぞ れの引張強度に依存するため、クリープ低減係数を見てみると、0.55〜0.65のものが多いが、中には 0.3 と低いものもある。ただしそれらは、元々の引張強度もかなり低いものである。

以上がジオグリッドのみを用いて空気中でその特性を調べたものであるが、耐衝撃性試験と土中引き 抜き試験はジオグリッドの土中での挙動を調心゙たものである。土中引き抜き試験に関しては次節でやや 詳しく述心゙るためここでは省略する。耐衝撃性試験であるが、これは「適切な施工管理下において、衝 揧後の強度保持率が確保され、十分な耐衝撃性を有している」ことを確認するために行われるものであ る。具体的な標準的試験条件としては、実地盤の上にまさ土、クラッシャラン (C-40)、岩ずりの 3 種の 試料土を撒き出し転圧・整地し下地を造成し、その上に供試体を敷設し、さらにバックホウ0.7 $\mathrm{m}^{3}$ で撒 き出し、ブルドーザ $21 \mathrm{t}$ 級で押土撒き出しし、その後振動ローラ（自重 $9 \mathrm{t}$ 、起振力 $98 \mathrm{kN}$ ）を用いて 7 回 転圧する。転圧終了後、資料を傷付けないように注意深く取り出し、引張試験を行い強度保持率を調心゙ る。A 試料など多くのジオグリッドでは以上のような仕様で行われているが、それ以外の試料土を用い ている場合には脚注を付けてある。この試験は実際の使用条件に近い状態を模擬して行われているため、 特に実用上重要な意味を持つのではないかと思われる。表 1 〜 6 をみと、ほとんどのジオグリッドで 強度保持率は概ね $90 \%$ を超えており、ここに示されたデータの範囲内では、岩ずりのようなものを用い て転圧を行っても損傷の程度は著しくなく、十分な強度が保持できていると言えよう。

3.引き抜き特性

ここでは補強土構造物の安定性に大きく関係するジオグリッドと土との摩擦特性について、土中引き 抜き試験結果をジオグリッドの特性との関係を検討してみる。なお、引き抜き試験の仕様は必ずしも同 一ではないが、ここでは特に区別しないで並列的に比較を行う。また、試料土は豊浦砂である。

まず様々な引張強度を有するジオグリッドについて、土とのせん断摩擦角 $\delta$ と土自体の内部摩擦角徐 比 $\tan \delta / \tan \phi$ を図 1 に示す。なお、各々の値は報告書の中の表中に明記してあったものはそれを用いた が、グラフのみが示してある場合には図から読み取った。図1を見るとかなりばらつきが大きくあまり

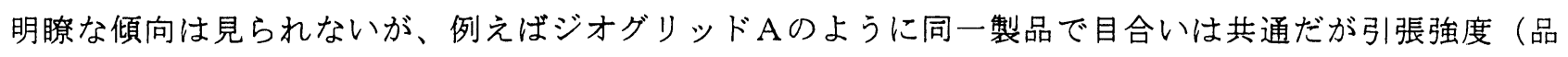
番）は異なるものを見てみると、 $\tan \delta / \tan \phi$ はジオグリッド自体の引張強度にはあまり依存していない ようである。また、若干 1 を上回るものもあるが、ほとんどのデータは 1 以下となっており、林ら ${ }^{21}$ がJewe11 ${ }^{3)}$ らの結果を紹介しているように、土とジオグリッドのせん断摩擦角 $\delta$ は土自体のせん断角 $\phi$ 
を超えることはないようである。Makiuchi\&Miyamori ${ }^{4)}$ もジオテキスタイルについて同様な結果を示し ている。ところで図 1 の中には $\tan \delta / \tan \phi$ が極端に小さな值を示すものもある。これは、引き抜き試験 においては数種類の上載圧の下で試験を実施し、上載圧と引き抜きせん断灾力の関係から $\delta$ 並びにcを 求めているが、多くの場合上載圧がせいぜい 3 種類である。従って、3つの点から直線の傾きと切片を 決めており、特に小さな上載圧の下での実験においてせん断抵抗が高めに出た場合に、摩擦角は小さめ に、粘着成分は高めに出てしまったものと思われる。そこで以降は、引き抜きせん断応力を各上載圧毎 にその上載圧での土自体のせん断強度で除した「引き抜き強度比」を用いることとする。

図 1 と同様に、ジオグリッドの引張強度が引き抜き特性に及ぼす影響を見たのが図2である。これも やはりばらつきは大きいが、極端に高い值を示す 1 点を除いて 0.5 ～1.5 とほぼ 1 前後の值を示している。 個別の数值をやや詳しく見ても、引張強度が高いほど引き抜き強度が高いということは必ずしもない。 同様の比較を交点強度や目合い（縌または横）についても行ったのが図 3、図 4である。これらを見て も、引き抜き強度はジオグリッド自体の特性にはあまり影響されず、それが敷設されている土自体の強 度でほとんど決まってくるようである。

次に引き抜け時にジオグリッドにどの程度のひずみが生じたかを見てみる。これに関しては、引き抜 き試験時にジオグリッドの複数点の変位計測值が報告書に示されていたジオグリッド $\mathrm{B}$ とジオグリッ ドDのみについて検討する。図 5 、図 6 は、種々の上載圧の下で、引き抜け時にジオグリッドに生じた ひずみを引張剛性に対してプロットしたものである。図中には各ジオグリッドの引張試験における破断 時のひずみも示してある。図 5 を見ると、引張剛性が高いほど引き抜け時のひずみは小さく、また上載 圧が低いほどひずみが小さい。ジオグリッドDについても同様な傾向を示すが、元々のびが小さいため、 引張剛性や上載圧一の依存性はジオグリッドBと比べ小さい。引き抜き強度は補強盛土の破壊に対する 安定性の検討に必要とされているが、今後は変形の程度も重要になると思われ、さらにこのようなデー タの報告がなされることが望まれる。

4.まとめ

1)公表された一連の報告書に基づき、11種類のジオグリッドについて特性が取りまとめられた。

2)引き抜き強度は引張強度・交点強度・目合いなどジオグリッドの特性よりも土の強度に依存する。

3)引き抜け時のひずみは、ジオグリッドの引張剛性が高いほど、また上載圧が小さいほど、小さい。 謝辞：日本大学巻内勝彦教授には参考文献をご紹介いただいた。記して謝意を表する。 参考文献

1) Akagi, T., Higuchi, T. and Chida, S.: Engineering properties of five major geogrids in Japan, Proc. 5th Int. Conf. on Geotextiles, Geomembranes and Related Products, Singapore, Vol.1, pp.401-404, 1994.

2) 林重徳, 阿部裕, 岩崎高明, 岡村康弘, 川崎広貴:「土とジオテキスタイルの摩擦特性試験方法」につ いて, ジオテキスタイル試験方法に関するシンポジウム発表論文集, 東京, 土質工学会, pp.1-8, 1994.

3) Jewell, R.A., Milligan, G.W.E., Sarsby, R.W. and DuBois, D.: Interaction between soil and geogrids, Proc. Symposium on Polymer Grid Reinforcement in Civil Engineering, London, pp.1-13, 1984.

4) Makiuchi, K. and Miyamori, T.: Mobilization of soil-geofabric interface friction, Proc. Int. Geotechnical Symposium on Theory and Practice of Earth Reinforcement, Fukuoka, Balkema, Vol.1, pp.129-134, 1988. 
表 1 ジオグリッドA，B特性

\begin{tabular}{|c|c|c|c|c|c|c|c|c|c|c|}
\hline 製品名 & & & \multicolumn{4}{|c|}{ A } & \multicolumn{4}{|c|}{$\mathrm{B}$} \\
\hline 品番 & & & A1 & A2 & A3 & A4 & B1 & B2 & B3 & B4 \\
\hline \multirow[b]{2}{*}{ 素材構成 } & $\frac{\text { 芯材 }}{\text { 華杜(樺) }}$ & & \multirow{2}{*}{\multicolumn{4}{|c|}{ 延伸ポリプロピレンテープ }} & \multicolumn{4}{|c|}{ 高強度·低伸度ポリエステルフィラメント } \\
\hline & $\begin{array}{c}\text { 芯材(横) } \\
\frac{\text { 被夏材 }}{2}\end{array}$ & & & \multicolumn{3}{|c|}{ エチレン·酢酸ビニル共重合樹脂 } & \multicolumn{4}{|c|}{ アクリル酸エステル含有アクリル系樹脂 } \\
\hline \multirow{2}{*}{ 䙺格 } & 目合い(絴) & $\bar{m}$ & \multicolumn{4}{|c|}{0.040} & \multicolumn{4}{|c|}{0.017} \\
\hline & $\| \hat{A} い($ 促 $)$ & iii & \multicolumn{4}{|c|}{0.080} & \multicolumn{4}{|c|}{0.017} \\
\hline \multirow{6}{*}{$\begin{array}{c}\text { 引張試験(*1) } \\
\text { (引張ひずみ速度 } \\
1 \% / \mathrm{mm})\end{array}$} & 供試体幅 & $\mathrm{m}$ & \multicolumn{4}{|c|}{0.20} & \multicolumn{4}{|c|}{0.20} \\
\hline & 引張強度 & $\mathrm{kN} / \mathrm{m}$ & 74.31 & 94.69 & 120.30 & 137.90 & 76.40 & 97.30 & 126.48 & 166.26 \\
\hline & 引張強度（横） & $\mathrm{kN} / \mathrm{m}$ & \multicolumn{4}{|c|}{ なし } & 3503 & 4280 & 5076 & 8132 \\
\hline & 破断時引張ひずみ & $\%$ & 6.92 & 6.46 & 6.86 & 6.17 & 12.90 & 12.00 & 13.20 & 11.90 \\
\hline & 破断時引張ひずみ(横) & $\%$ & \multicolumn{4}{|c|}{ なし } & 1180 & 1350 & 1840 & 1860 \\
\hline & 引張剛性 & $\mathrm{kN} / \mathrm{m}$ & 1202.04 & 1756.77 & 2095.82 & 2831.62 & 477.50 & 715.20 & 803.05 & 1039.12 \\
\hline \multirow{3}{*}{ 交点強度試験 } & 引張速度 & $\mathrm{mm} / \mathrm{min}$ & \multicolumn{4}{|c|}{200.00} & \multicolumn{4}{|c|}{100.00} \\
\hline & 交点強度 & $\mathrm{N}$ & 226.00 & 206.00 & 229.00 & 243.00 & 190.51 & 194.73 & 257.61 & 272.23 \\
\hline & 交点強度（横） & $\mathrm{N}$ & \multicolumn{4}{|c|}{ なし } & \multicolumn{4}{|c|}{ な } \\
\hline \multirow{3}{*}{ クリープ試轵 } & 供試体幅[ストランド数] & $\mathrm{m}$ & \multirow{2}{*}{\multicolumn{4}{|c|}{$\frac{\text { [2本] }}{0.65}$}} & \multirow{2}{*}{\multicolumn{4}{|c|}{$\frac{[3 \text { 本] }}{0.65}$}} \\
\hline & クリープ低減定数 & & & & & & & & & \\
\hline & クリープ限界強度 & $\mathrm{kN} / \mathrm{m}$ & 42.00 & 57.00 & 70.00 & 80.00 & 38.26 & 51.01 & 63.77 & 95.65 \\
\hline \multirow{5}{*}{ 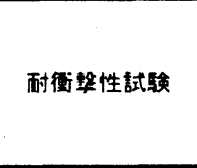 } & 供式体幅[ストランド数 $]$ & $m$ & \multicolumn{4}{|c|}{0.20} & \multicolumn{4}{|c|}{0.20} \\
\hline & 引張ひずみ速度 & $\% / \min$ & \multicolumn{4}{|c|}{20.00} & & & & \\
\hline & 强度保持隺（砕石 $c-40$ ) & $\%$ & 94.40 & 98.20 & 95.00 & 100.10 & 97.10 & 97.90 & & \\
\hline & 強度保持率(まささ) & $\%$ & 102.70 & 104.30 & 100.80 & 96.20 & 96.60 & 96.50 & なし & なし \\
\hline & 强度保持事(岩ずり) & $\%$ & 94.50 & 99.50 & 97.00 & 100.00 & 99.20 & 93.00 & & \\
\hline & 相対密度 & $\%$ & & & & & & & & \\
\hline 恄料土(䅧浦砂) & 粘举カc & $\mathrm{KPa}$ & & & & & & & & \\
\hline のせん断恄䮬結果 & 内部㨲角 $\phi$ & 度 & & & & & & & & \\
\hline & 䢀嬠密度 & $t / m^{3}$ & & & & & & & & \\
\hline & $c^{\prime}(* 2)$ & $\mathrm{kPa}$ & 186 & 104 & 869 & $18 \%$ & 13.93 & 11.18 & 3.34 & 7.16 \\
\hline 土中引き报き試娩 & $\delta(* 2)$ & 度 & 296 & 2396 & 2368 & 2328 & 30.50 & 32.10 & 39.70 & 39.20 \\
\hline & $\tan (\delta) / \tan (\phi)$ & & 0.88 & 0.69 & 0.69 & 0.66 & 0.75 & 0.80 & 1.06 & 1.04 \\
\hline
\end{tabular}

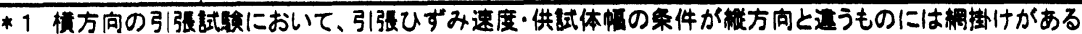

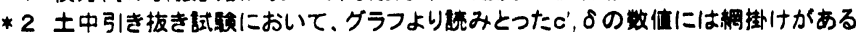

表 2 ジオグリッドCり特性

\begin{tabular}{|c|c|c|c|c|c|c|c|c|c|c|}
\hline 製品名 & & \multicolumn{9}{|c|}{ C } \\
\hline 晶蹎 & & $\mathrm{Cal}$ & $\mathrm{Ca} 2$ & $\mathrm{Ca} 3$ & $\mathrm{Ca}_{\mathrm{a}}$ & $\mathrm{Ca} 5$ & $\mathrm{Ca}_{\mathrm{a}}$ & $\mathrm{Cb} 1$ & $\mathrm{Cb} 2$ & $\mathrm{Cb3}$ \\
\hline 芯材 & & \multirow{3}{*}{\multicolumn{6}{|c|}{$\begin{array}{l}\text { 高密度ポリエチレン } \\
\text { (制法:一方向延伸) }\end{array}$}} & \multirow{3}{*}{\multicolumn{3}{|c|}{$\begin{array}{c}\text { ポリプロピレン } \\
\text { (製法:=方向延伸) }\end{array}$}} \\
\hline 殸材 (模) & & & & & & & & & & \\
\hline 被怔材 & & & & & & & & & & \\
\hline 目合い(継) & $m$ & \multicolumn{6}{|c|}{0.166} & \multicolumn{3}{|c|}{0.028} \\
\hline 目合い(模) & $\mathrm{m}$ & \multicolumn{6}{|c|}{0.022} & \multicolumn{2}{|c|}{0.040} & 0.033 \\
\hline 供弑体幅 & $\mathrm{m}$ & \multicolumn{6}{|c|}{0.22} & \multicolumn{3}{|c|}{0.22} \\
\hline 引引镸強度 & $\mathrm{kN} / \mathrm{m}$ & 41.40 & 56.00 & 67.60 & 77.70 & 100.20 & 109.10 & 13.30 & 20.60 & 36.20 \\
\hline 引镸強度（模） & $\mathrm{kN} / \mathrm{m}$ & \multicolumn{6}{|c|}{ なし } & 22.70 & 35.10 & 43.70 \\
\hline 破断時引張ひずみ & $\%$ & 20.70 & 20.00 & 21.70 & 22.00 & 15.70 & 14.60 & 19.80 & 19.70 & 14.70 \\
\hline 破断時引張ひずみ(榙) & $\%$ & \multicolumn{6}{|c|}{ なし } & 13.50 & 14.60 & 15.50 \\
\hline 引張剛性 & $\mathrm{kN} / \mathrm{m}$ & 419.54 & 608.03 & 664.70 & 777.00 & 918.42 & 1242.03 & 183.80 & 315.85 & 452.50 \\
\hline 引引張速度 & $\mathrm{mm} / \mathrm{min}$ & \multicolumn{6}{|c|}{$[20 \% / \mathrm{min}]$} & \multicolumn{3}{|c|}{$[20 \% / \mathrm{min}]$} \\
\hline 交点強度 & $\mathrm{N}$ & 1136.00 & 1548.00 & 1872.00 & 2133.00 & 2685.00 & 2952.00 & 556.00 & 849.00 & 1089.00 \\
\hline 交点強度（棤） & $\mathrm{N}$ & \multicolumn{6}{|c|}{ なし } & 576.00 & 962.00 & 1027.00 \\
\hline 供試体幅[ストランド数] & $m$ & & & & & & & \multicolumn{3}{|c|}{ [2本] } \\
\hline クリープ低減定数 & & \multicolumn{6}{|c|}{0.60} & \multicolumn{2}{|c|}{0.30} & 0.40 \\
\hline クリープ限界強度 & $\mathrm{kN} / \mathrm{m}$ & 21.60 & 30.00 & 36.00 & 42.00 & 54.00 & 60.00 & 3.00 & 5.10 & 10.80 \\
\hline 供試体幅[ストランド数 $]$ & $\mathrm{m}$ & \multicolumn{6}{|c|}{ 広幅 } & \multicolumn{3}{|c|}{ 広幅 } \\
\hline 引張ひずみ速度 & $\% / \min$ & \multicolumn{6}{|c|}{20.00} & \multicolumn{3}{|c|}{20.00} \\
\hline 強度保持率(砕石 $c-40$ ) & $\%$ & \multirow{3}{*}{ なし } & 88.60 & \multirow{3}{*}{ なし } & 85.30 & \multirow{3}{*}{ なし } & 92.30 & \multirow{3}{*}{ なし } & \multirow{3}{*}{ なし } & 105.00 \\
\hline 强度保持率(まさ士) & $\%$ & & 97.10 & & 92.60 & & 99.20 & & & 100.00 \\
\hline 強度保持率(岩ずり) & $\%$ & & 85.70 & & 82.10 & & 92.30 & & & 105.00 \\
\hline 相対密度 & $\%$ & \multicolumn{6}{|c|}{80.00} & \multicolumn{3}{|c|}{80.00} \\
\hline 粘着力c & $\mathrm{KPa}$ & & & & & & & & 0.00 & \\
\hline 内部摩撩角 $\phi$ & 度 & & & & & & & & 38.00 & \\
\hline 乾燥密度 & $t / m^{3}$ & & & & & & & & 1.50 & \\
\hline$c^{\prime}(* 2)$ & $\mathrm{kPa}$ & 1.00 & & & 2.20 & & 2.50 & & 0.50 & 0.10 \\
\hline$\delta(* 2)$ & 度 & 35.90 & なし & なし & 32.70 & なし & 34.30 & なし & 34.40 & 36.30 \\
\hline $\tan (\delta) / \tan (\phi)$ & & 0.93 & & & 0.82 & & 0.87 & & 0.88 & 0.94 \\
\hline
\end{tabular}


表 3 ジオグリッドDの特性

\begin{tabular}{|c|c|c|c|c|c|c|c|c|c|c|c|}
\hline 製品名 & & \multicolumn{10}{|c|}{$D$} \\
\hline 品番 & & $\mathrm{Da} 1$ & $\mathrm{Da} 2$ & Da3 & $\mathrm{Da} 4$ & Da5 & Da6 & Db1 & $\mathrm{Db} 2$ & Db3 & Db4 \\
\hline 芯材 & & \multirow{2}{*}{\multicolumn{6}{|c|}{ テクノーラ }} & \multicolumn{4}{|c|}{ テクノーラ・ポリエステル } \\
\hline 芯材 (横) & & & & & & & & \multicolumn{4}{|c|}{ ポリエステル } \\
\hline 被覆材 & & \multicolumn{6}{|c|}{ 高密度ポリエチレン } & \multicolumn{4}{|c|}{ 塩化ビニル系樹脂 } \\
\hline 目合い(絴) & $m$ & \multicolumn{6}{|c|}{0.026} & \multicolumn{4}{|c|}{0.018} \\
\hline 目合い(横) & $\mathbf{m}$ & \multicolumn{6}{|c|}{0.028} & \multicolumn{4}{|c|}{0.016} \\
\hline 供試体幅 & $\mathrm{m}$ & \multicolumn{6}{|c|}{0.22} & \multicolumn{4}{|c|}{0.20} \\
\hline 引張強度 & $\mathrm{kN} / \mathrm{m}$ & 36.79 & 48.66 & 60.43 & 83.19 & 98.98 & 118.11 & 81.62 & 93.98 & 150.19 & 191.39 \\
\hline 引張強度 (横) & $\mathrm{kN} / \mathrm{m}$ & 1383 & 1402 & 1432 & 1403 & 1432 & 149 & 76.42 & 92.70 & 92.90 & 93.39 \\
\hline 破断時引張ひずみ & $\%$ & 3.58 & 3.56 & 3.61 & 3.85 & 3.57 & 3.52 & 5.17 & 5.11 & 5.08 & 5.16 \\
\hline 破断時引張ひずみ(横) & $\%$ & 803 & 191 & 159 & 132 & 835 & 850 & 13.79 & 14.11 & 13.92 & 13.89 \\
\hline 引張剛性 & $\mathrm{kN} / \mathrm{m}$ & 821.52 & 895.76 & 1112.47 & 1682.62 & 2210.43 & 2628.22 & 1160.68 & 1277.59 & 2041.75 & 2439.37 \\
\hline 引張速度 & $\mathrm{mm} / \mathrm{min}$ & \multicolumn{6}{|c|}{100.00} & \multicolumn{4}{|c|}{100.00} \\
\hline 交点強度 & $\mathrm{N}$ & 631.86 & 643.83 & 676.20 & 647.36 & 649.62 & 670.32 & 81.23 & 84.66 & 94.76 & 97.22 \\
\hline 交点強度 (横) & $N$ & \multicolumn{6}{|c|}{ なし } & \multicolumn{4}{|c|}{ なし } \\
\hline 供試体幅[ストランド数] & $m$ & \multicolumn{6}{|c|}{ [3本] } & \multicolumn{4}{|c|}{ [4本] } \\
\hline クリープ低減定数 & & \multicolumn{6}{|c|}{0.60} & \multicolumn{4}{|c|}{0.60} \\
\hline クリープ限界強度 & $\mathrm{kN} / \mathrm{m}$ & 19.00 & 27.00 & 33.00 & 46.00 & 57.00 & 67.00 & 44.00 & 54.00 & 87.00 & 110.00 \\
\hline 供試体幅[ストランド数] & $\mathrm{m}$ & \multicolumn{6}{|c|}{0.20} & \multicolumn{4}{|c|}{0.20} \\
\hline 引張ひずみ速度 & $\% / \min$ & \multicolumn{6}{|c|}{20.00} & \multicolumn{4}{|c|}{20.00} \\
\hline 強度保持率(砕石 $c-40$ ) & $\%$ & 96.60 & \multirow{3}{*}{ なし } & 95.40 & \multirow{3}{*}{ なし } & 101.70 & & \multirow{3}{*}{ なし } & 101.30 & \multirow{3}{*}{ なし } & 97.70 \\
\hline 強度保持率(まさ土) & $\%$ & 96.80 & & 101.30 & & 102.30 & なし & & 102.80 & & 96.70 \\
\hline 強度保持率(岩ずり) & $\%$ & 97.10 & & 94.70 & & 102.40 & & & 94.30 & & 96.90 \\
\hline 相対密度 & $\%$ & & & & & & & & & & \\
\hline 粘着力c & $\mathrm{kPa}$ & & & & & & & & & & \\
\hline 内部摩擦角 $\phi$ & 度 & & & & & & & & & & \\
\hline 乾燥密度 & $t / m^{3}$ & & & & & & & & & & \\
\hline$c^{\prime}(* 2)$ & $\mathrm{kPa}$ & 6.87 & & 2.94 & & 6.87 & 7.85 & & 0.98 & & 4.91 \\
\hline$\delta(* 2)$ & 度 & 35.00 & なし & 41.10 & なし & 38.60 & 38.70 & なし & 35.00 & なし & 34.60 \\
\hline $\tan (\delta) / \tan (\phi)$ & & 0.86 & & 1.08 & & 0.99 & 0.99 & & 0.86 & & 0.85 \\
\hline
\end{tabular}

\begin{tabular}{|c|c|c|c|c|c|c|c|c|c|c|c|}
\hline 製品名 & & \multicolumn{4}{|c|}{$E$} & \multicolumn{3}{|c|}{$\mathrm{F}$} & \multicolumn{3}{|c|}{ G } \\
\hline 品番 & & E1 & E2 & E3 & E4 & F1 & F2 & F3 & G1 & G2 & G3 \\
\hline $\begin{array}{c}\text { 芯材 } \\
\text { 芯材 (横) }\end{array}$ & & \multicolumn{4}{|c|}{ テナックSD } & \multicolumn{3}{|c|}{ ダイオレン } & \multicolumn{3}{|c|}{ ポリエステル系特殊辖維 } \\
\hline 被覆材 & & \multicolumn{4}{|c|}{ 合成樹脂(エチレン・酢酸ビニル共重合樹脂) } & \multicolumn{3}{|c|}{ 塩化ビニール } & \multicolumn{3}{|c|}{ 塩化ビニール系樹脂 } \\
\hline 目合い(縦) & $\mathrm{m}$ & \multicolumn{2}{|c|}{0.050} & \multicolumn{2}{|c|}{0.040} & 0.020 & 0.006 & 0.020 & \multicolumn{3}{|c|}{0.020} \\
\hline 目合い(横) & $\mathrm{m}$ & \multicolumn{3}{|c|}{0.050} & 0.040 & 0.020 & 0.006 & 0.020 & \multicolumn{3}{|c|}{0.020} \\
\hline 供試体幅 & $\mathrm{m}$ & \multicolumn{4}{|c|}{0.20} & \multicolumn{3}{|c|}{0.20} & \multicolumn{3}{|c|}{0.20} \\
\hline 引張強度 & $\mathrm{kN} / \mathrm{m}$ & 57.49 & 57.49 & 72.10 & 72.10 & 54.64 & 77.11 & 114.29 & 38.75 & 59.64 & 80.93 \\
\hline 引張強度 (横) & $\mathrm{kN} / \mathrm{m}$ & 3002 & 5449 & 2992 & 7210 & なし & 79.36 & なし & 3443 & 5062 & 1220 \\
\hline 破断時引張ひずみ & $\%$ & 6.80 & 6.80 & 6.70 & 6.70 & 12.60 & 10.50 & 13.80 & 12.98 & 12.72 & 12.89 \\
\hline 破断時引張ひずみ(横) & $\%$ & 650 & 680 & 650 & 610 & なし & 13.00 & なし & 1540 & 1424 & 1561 \\
\hline 引張剛性 & $\mathrm{kN} / \mathrm{m}$ & 1006.07 & 958.11 & 1201.73 & 1201.73 & 344.92 & 565.63 & 596.55 & 261.57 & 397.63 & 490.50 \\
\hline 引張速度 & $\mathrm{mm} / \mathrm{min}$ & \multirow{3}{*}{ なし } & 100. & \multirow{3}{*}{ なし } & \multirow{3}{*}{ なし } & \multicolumn{3}{|c|}{200.00} & \multicolumn{3}{|c|}{50.00} \\
\hline 交点強度 & $\mathrm{N}$ & & 962.36 & & & 69.65 & 227.59 & 166.77 & 133.42 & 140.28 & 152.06 \\
\hline 交点強度(横) & $N$ & & なし & & & なし & 112.82 & なし & \multicolumn{3}{|c|}{ なし } \\
\hline 供試体幅[ストランド数] & $\mathrm{m}$ & \multicolumn{4}{|c|}{0.20} & [3本] & [5本] & [3本] & \multicolumn{3}{|c|}{ [3本] } \\
\hline クリープ低減定数 & & \multicolumn{4}{|c|}{0.60} & 0.65 & 0.60 & 0.65 & \multicolumn{3}{|c|}{0.65} \\
\hline クリープ限界強度 & $\mathrm{kN} / \mathrm{m}$ & 32.37 & 32.37 & 41.20 & 41.20 & 31.88 & 41.20 & 63.77 & 19.00 & 29.00 & 38.00 \\
\hline 供試体幅[ストランド数] & $m$ & \multicolumn{4}{|c|}{$?$} & & $?$ & & & 0.20 & \\
\hline 引張ひずみ速度 & $\% / \min$ & & 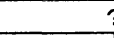 & & & & $?$ & & & 20.00 & \\
\hline 強度保持率(砕石 $c-40)$ & $\%$ & & & & & 97 & 00 & 9900 & & 94.70 & \\
\hline 強度保持率(まささ) & $\%$ & なし & $\alpha$ & なし & & & なし & & なし & 98.10 & なし \\
\hline 強度保持事(岩ずり) & $\%$ & & 960003 & & $96,60(<3)$ & 9000 & 99000 & $10000+3$ & & 92.90 & \\
\hline 相対密度 & $\%$ & & 44 & & & & $?$ & & & 81.20 & \\
\hline 粘着力c & $\mathrm{kPa}$ & & 3 & & & & $?$ & & & 0.00 & \\
\hline 内部摩擦角 $\phi$ & 度 & & 3 & & & & $?$ & & & 38.00 & \\
\hline 乾燥密度 & $t / m^{3}$ & & 1. & & & & 1.47 & & & 1.58 & \\
\hline$c^{\prime}(* 2)$ & $\mathrm{kPa}$ & 258 & 558 & 48 & 48 & 1020 & 031 & 78 & 7.85 & 14.72 & 2.94 \\
\hline$\delta(* 2)$ & 度 & 2780 & 2090 & 2640 & 2610 & 110 & 3250 & 2540 & 31.80 & 29.70 & 39.20 \\
\hline $\tan (\delta) / \tan (\phi)$ & & & 3 & & & & $?$ & & 0.79 & 0.73 & 1.04 \\
\hline
\end{tabular}

*3 耐衝撃試験において試料土に粒度調整砕石 $(M-40)$ を用いた埸合の強度保持率

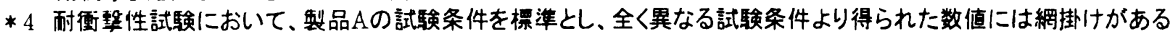




\begin{tabular}{|c|c|c|c|c|c|c|c|c|c|c|}
\hline 製品名 & & \multicolumn{4}{|c|}{$\mathrm{H}$} & \multicolumn{5}{|c|}{1} \\
\hline 品番 & & $\mathrm{HI}$ & $\mathrm{H} 2$ & $\mathrm{H} 3$ & $\mathrm{H} 4$ & 11 & 12 & 13 & 14 & 15 \\
\hline 芯材 & & \multicolumn{4}{|c|}{ 高強カビニロンフィラメント } & \multirow{3}{*}{\multicolumn{5}{|c|}{$\begin{array}{c}\text { ガラス緎維とビニルエステル樹脂によるFRP } \\
\text { (䌦維強化プラスチック） }\end{array}$}} \\
\hline 芯材 (横) & & 高強力 & 低伸度ポリコ & エステルフィ & ラメント & & & & & \\
\hline 被覆材 & & \multicolumn{4}{|c|}{ スチレン系アクリル樹脂 } & & & & & \\
\hline 目合い(絴) & $m$ & 0.016 & 0.018 & 0.019 & 0.020 & \multicolumn{5}{|c|}{0.100} \\
\hline 目合い(横) & $m$ & 0.018 & 0.019 & 0.020 & 0.020 & \multicolumn{5}{|c|}{0.030} \\
\hline 供試体幅 & $m$ & \multicolumn{4}{|c|}{0.20} & \multicolumn{5}{|c|}{0.24} \\
\hline 引張強度 & $\mathrm{kN} / \mathrm{m}$ & 37.73 & 57.35 & 87.13 & 107.43 & 64.26 & 96.53 & 125.47 & 177.27 & 260.46 \\
\hline 引張強度 (横) & $\mathrm{kN} / \mathrm{m}$ & $22.03(* 3)$ & $32.92(* 3)$ & $42.46(* 3)$ & $52.20(* 3)$ & \multicolumn{5}{|c|}{ なし } \\
\hline 破断時引張ひずみ & $\%$ & 4.43 & 5.70 & 6.04 & 6.79 & 2.21 & 2.01 & 2.15 & 1.96 & 2.23 \\
\hline 破断時引張ひずみ(横) & $\%$ & $15.30(* 3)$ & $14.10(* 3)$ & $14.10(* 3)$ & $15.10(* 3)$ & \multicolumn{5}{|c|}{ なし } \\
\hline 引張剛性 & $\mathrm{kN} / \mathrm{m}$ & 741.83 & 841.14 & 1308.29 & 1237.66 & 2947.50 & 4977.33 & 6090.77 & 9750.64 & 11947.50 \\
\hline 引張速度 & $\mathrm{mm} / \mathrm{min}$ & \multicolumn{4}{|c|}{1.50} & \multicolumn{5}{|c|}{1.50} \\
\hline 交点強度 & $\mathrm{N}$ & 72.01 & 77.89 & 107.71 & 168.14 & 910.37 & 1261.57 & 1589.22 & 2448.58 & 3186.29 \\
\hline 交点強度(横) & $N$ & \multicolumn{4}{|c|}{ なし } & \multicolumn{5}{|c|}{ なし } \\
\hline 供試体幅[ストランド数] & $m$ & \multicolumn{4}{|c|}{ [3本] } & \multicolumn{5}{|c|}{ [2本] } \\
\hline クリープ低減定数 & & \multicolumn{4}{|c|}{0.60} & \multicolumn{5}{|c|}{0.60} \\
\hline クリープ限界強度 & $\mathrm{kN} / \mathrm{m}$ & 20.60 & 32.37 & 47.09 & 58.86 & 29.43 & 47.09 & 58.86 & 88.29 & 117.72 \\
\hline 供試体幅[ストランド数] & $m$ & \multicolumn{4}{|c|}{ [1本] } & \multicolumn{5}{|c|}{ [1本] } \\
\hline 引張ひずみ速度 & $\% / \min$ & \multicolumn{4}{|c|}{33.30} & \multicolumn{5}{|c|}{1.00} \\
\hline 強度保持率(砕石 $c-40)$ & $\%$ & 90.00 & 96.00 & 90.00 & 93.00 & 8950 & \multirow{3}{*}{ なし } & 872 & \multirow{3}{*}{ なし } & 8710 \\
\hline 強度保持率(まさ土) & $\%$ & 92.00 & 97.00 & 91.00 & 97.00 & 933005 & & 91600 & & $9540+5$ \\
\hline 強度保持率(岩ずり) & $\%$ & \multicolumn{4}{|c|}{ なし } & 980006 & & $9060 \mathrm{O}-6$ & & $1048+8$ \\
\hline 相対密度 & $\%$ & \multicolumn{4}{|c|}{$?$} & & & $?$ & & \\
\hline 粘着力c & $\mathrm{kPa}$ & & 0.0 & 00 & & & & 0.00 & & \\
\hline 内部摩擦角 $\phi$ & 度 & & 32. & .60 & & & & 40.50 & & \\
\hline 乾㜭密度 & $t / m^{3}$ & & 1.4 & 49 & & & & 1.52 & & \\
\hline$c^{\prime}(* 2)$ & $\mathrm{kPa}$ & 084 & 307 & 307 & 223 & 2905 & 1509 & 2264 & 1358 & 132 \\
\hline$\delta(* 2)$ & 度 & 35.20 & 30.50 & 37.70 & 33.50 & 100 & 200 & 229 & 3160 & 3080 \\
\hline $\tan (\delta) / \tan (\phi)$ & & 1.10 & 0.92 & 1.21 & 1.03 & 0.25 & 0.47 & 0.49 & 0.72 & 0.70 \\
\hline
\end{tabular}

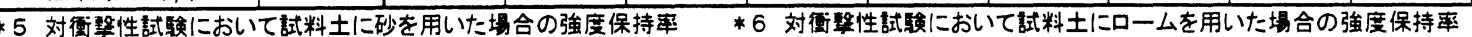
表 6 ジオグリッド J, Kの特性

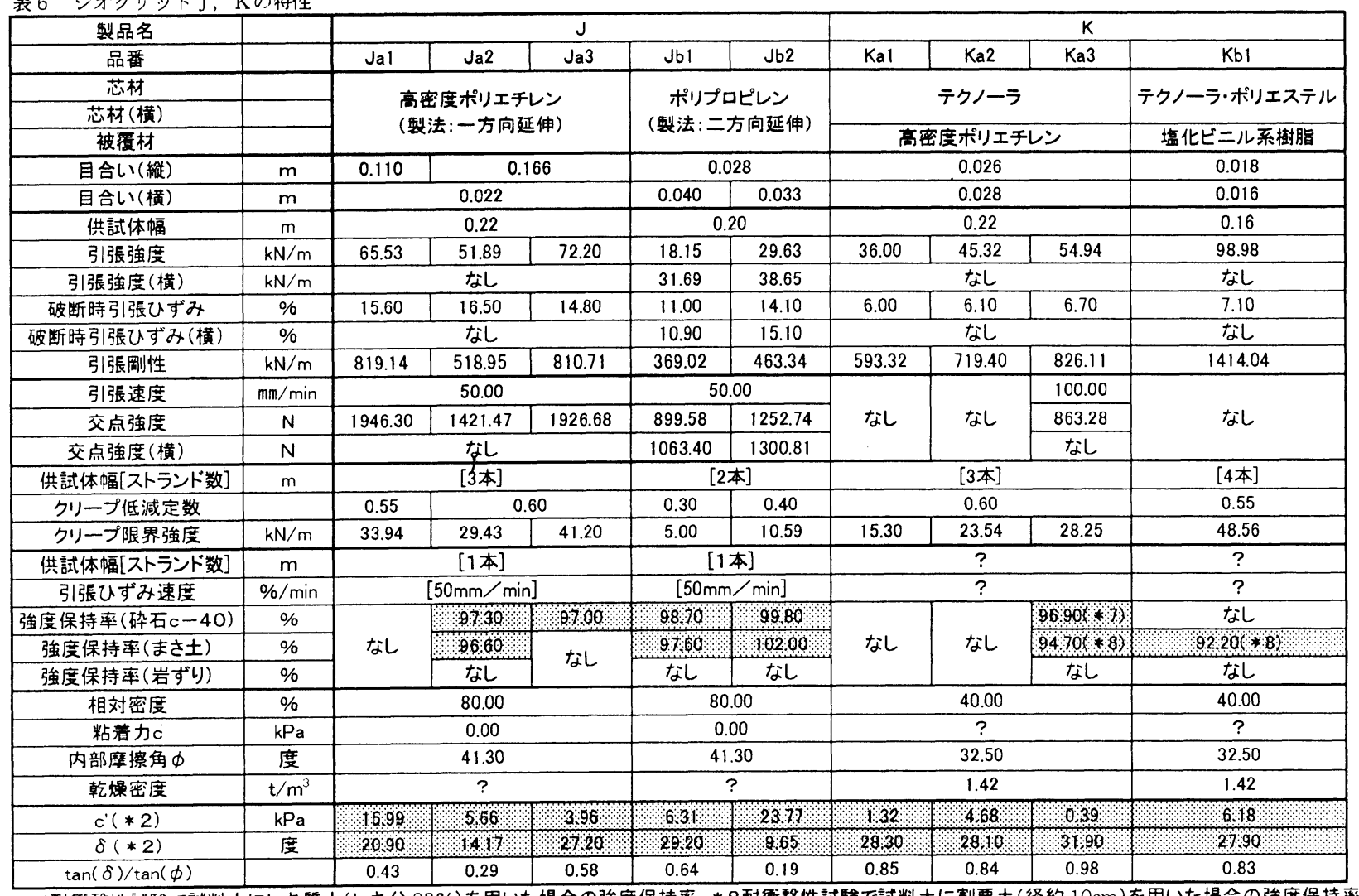

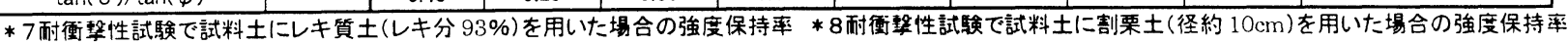




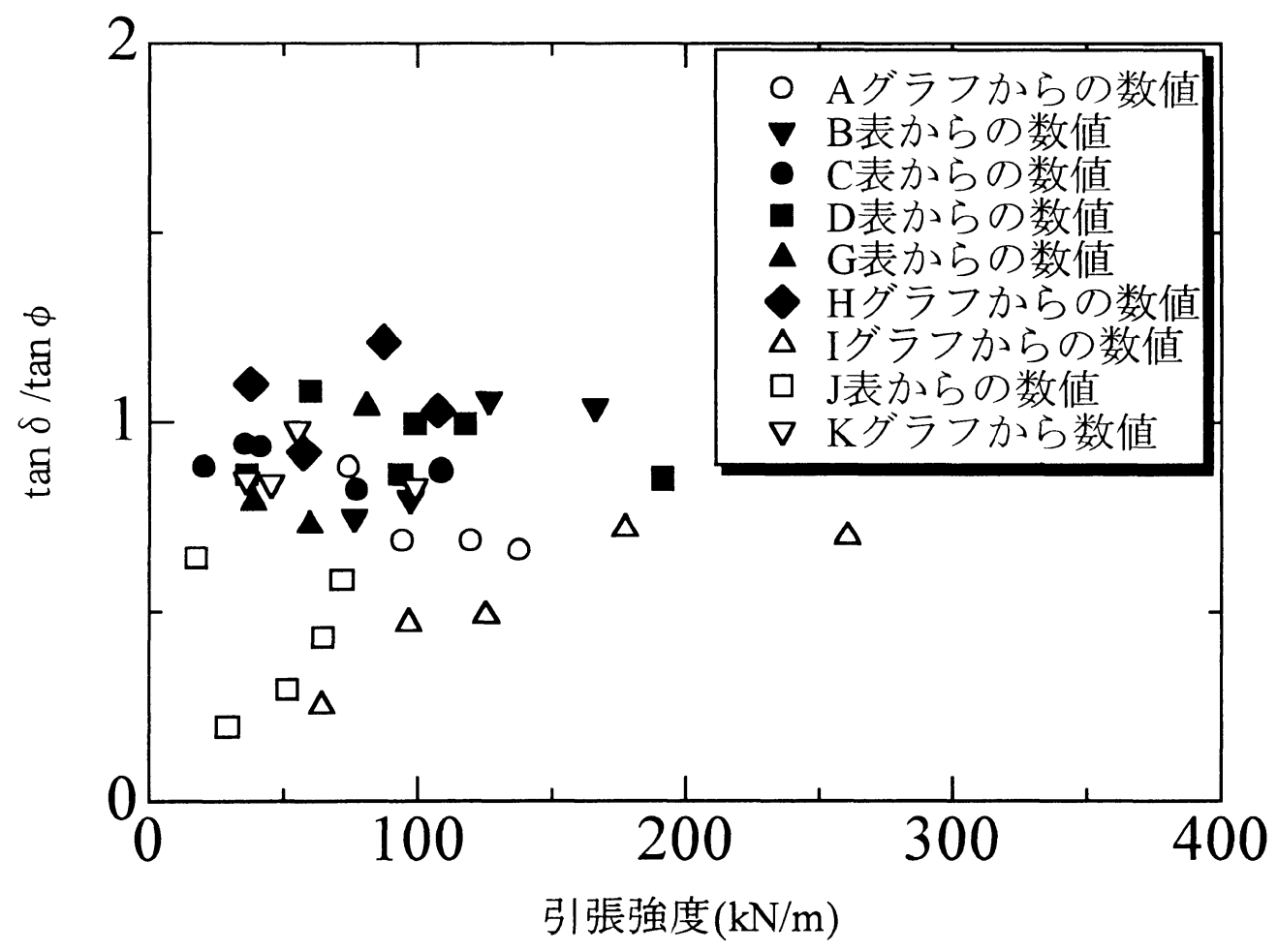

図 $1 \tan \delta / \tan \phi$ と引張強度の関係

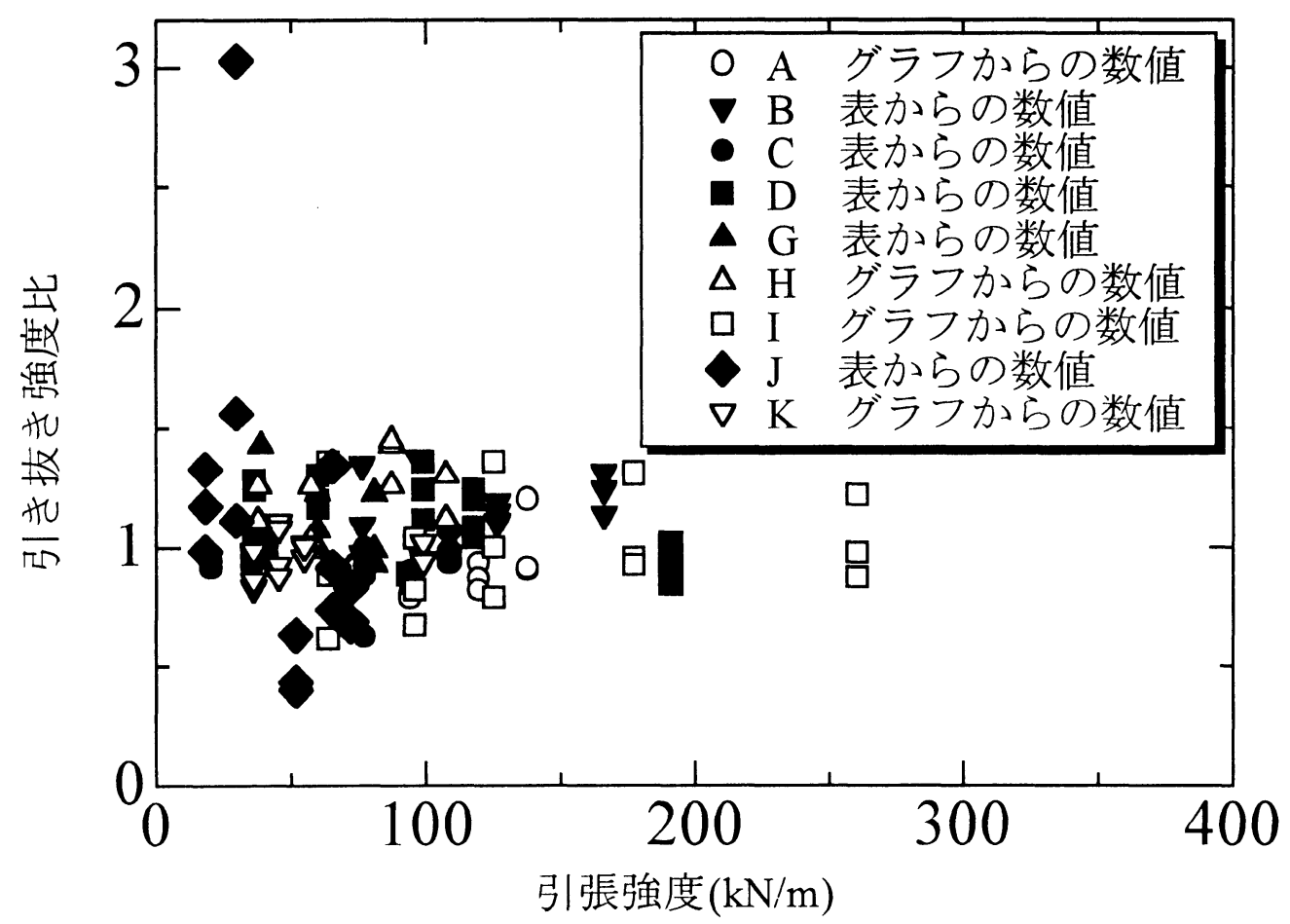

図 2 引き抜き強度比と引張強度の関係 


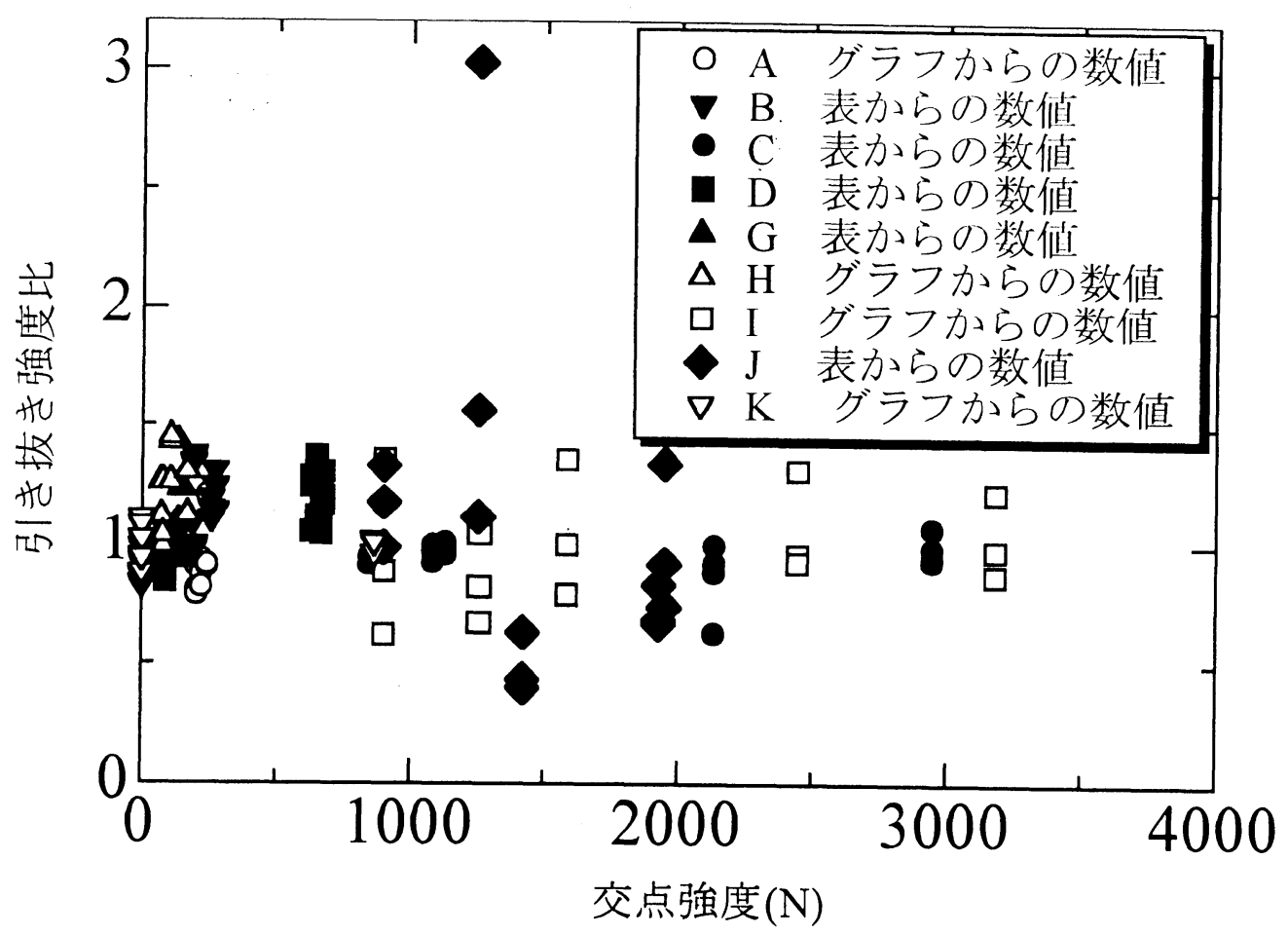

図 3 引き抜き強度比と交点強度の関係

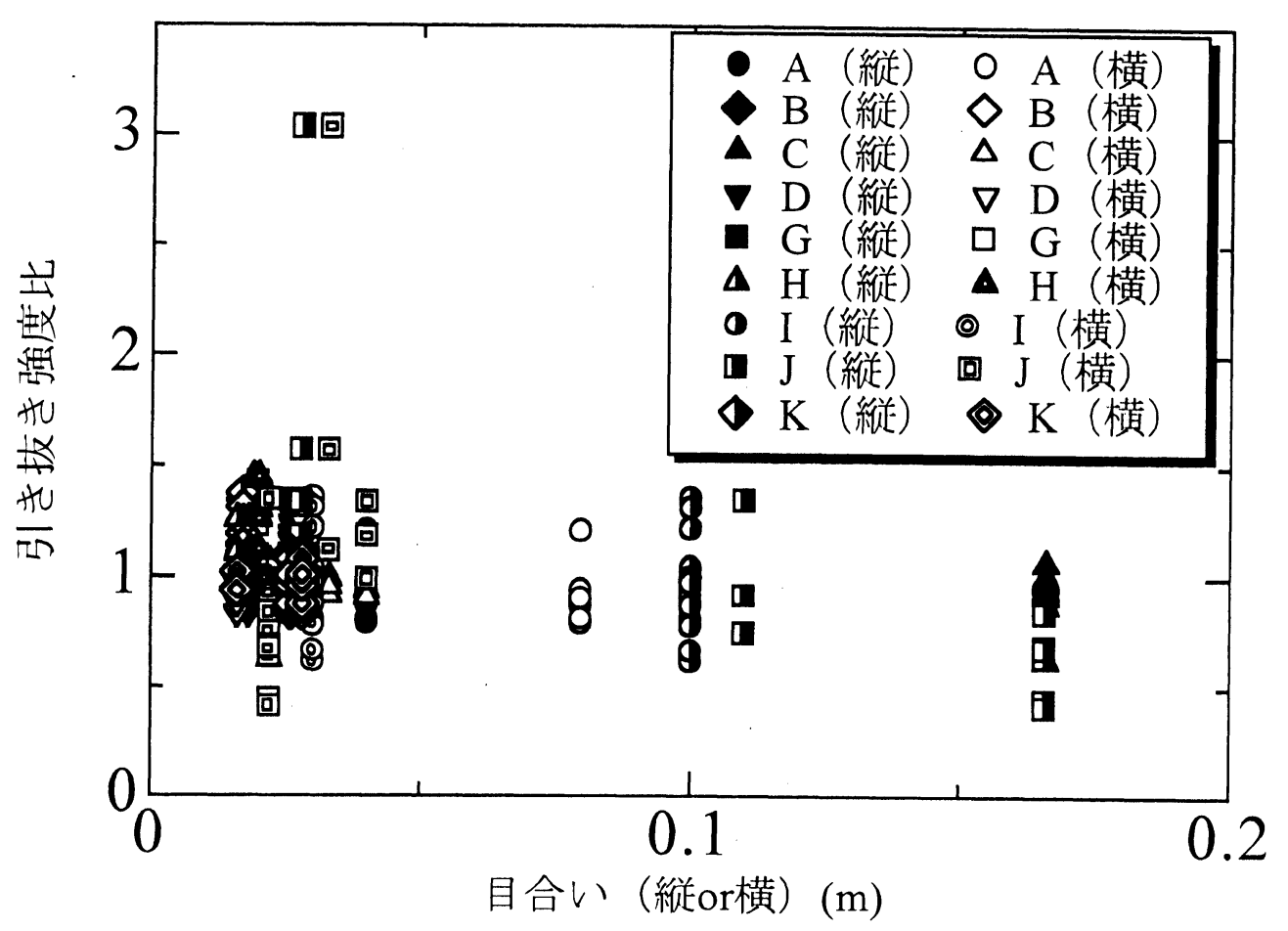

図4引き抜き強度比と目合いの関係 


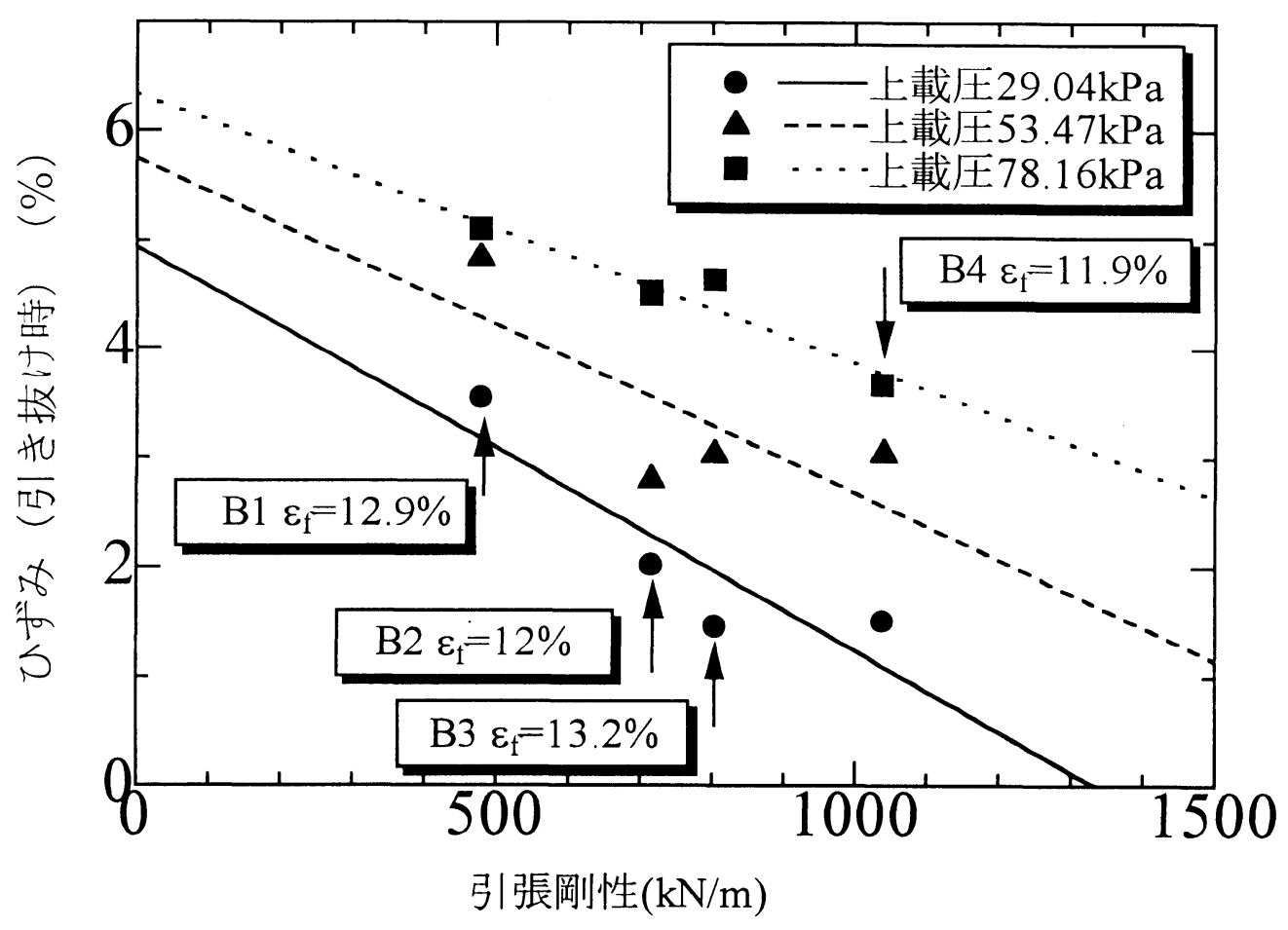

図 5 引き抜け時ひずみと引張剛性の関係（ジオグリッドB）

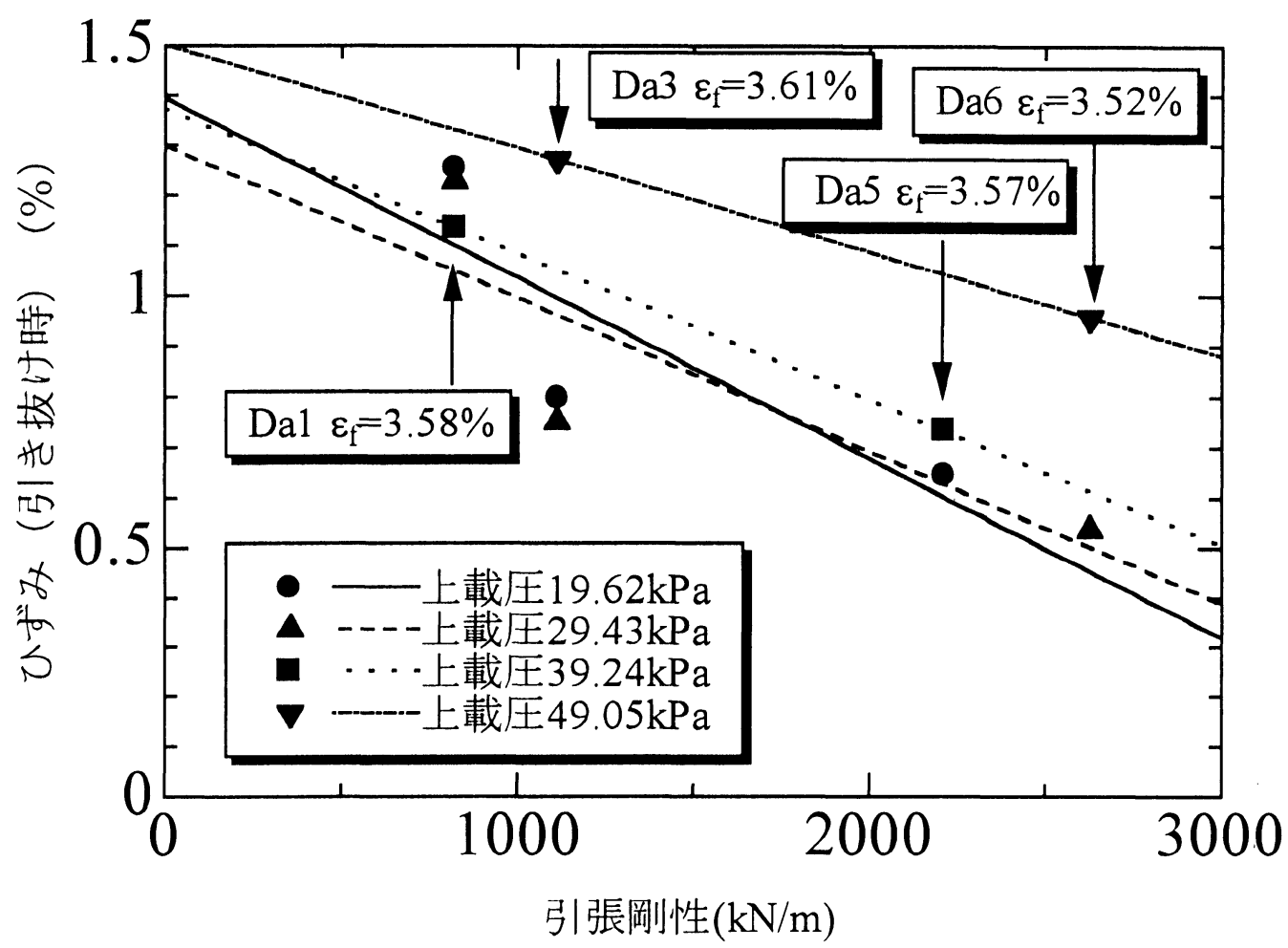

図6引引き抜け時ひずみと引張剛性の関係（ジオグリッドD） 